\title{
МІСЦЕ СУДОВО-ПСИХОЛОГІЧНОЇ ЕКСПЕРТИЗИ В КРИМІНАЛЬНОМУ ПРОЦЕСІ ТА АЛГОРИТМ ПРОВЕДЕННЯ ПСИХОДІАГНОСТИЧНОГО ДОСЛІДЖЕННЯ НЕПОВНОЛІТНІХ ЖЕРТВ НАСИЛЬСТВА
}

\author{
УДК: 343.988
}

\author{
Козлова Анна Георгї̈на \\ Аспірант кафедри психодіагностики та клінічної \\ психології, Київський національний університет \\ імені Тараса Шевченка, \\ Киів (Україна)
}

\begin{abstract}
Анотація. У даній статті розкрито основні положення щзодо організації та проведення судово-психологічної експертизи неповнолітніх жертв насильства. Розглянуто поняття фізичного, сексуального та психологічного насильства над дитиною. Теоретично проаналізовано місце судово-психологічної експертизи неповнолітніх жертв насильства та ї̈ значення в кримінальному прочесі. Визначено предмет, об'єкт та завдання судово-психологічної експертизи. Розглянуто особливості прояву психотравматизащії дитини як наслідка насильства. Розроблено алгоритм психодіагностичного інструментарію відповідно до вікових періодів неповнолітніх жертв насильства.
\end{abstract}

Ключові слова: алгоритм, психодіагностика, психологічне насильство, сексуальне насильство, судово-психологічна експертиза, неповнолітня жертва насильства, фізичне насильство.

Постановка проблеми. Судово- якої набула жертва посягання. Адже травмапсихологічна експертиза (далі - СПЕ) являє тизація неповнолітньої жертви насильницькособою спеціальне дослідження та оцінка явищ правової дійсності спеціалістом в галузі психології. Дане спеціальне психологічне дослідження проводиться в непсихологічній сфері - в практиці правоохоронних або судових органів.

Кримінально-правове значення СПЕ го посягання може бути не лише очевидною (фізичною), але й неочевидною (психологічною). Така психологічна посттравматична шкода, внаслідок її відтермінованості та латентності може бути невизначена судом i не врахована при кваліфікації ступеня суспільної небезпеки інкримінованого діяння. Чеполягає в індивідуалізації покарання та правирез це злочинець може уникнути відповідальльній кваліфікації злочину залежно від шкоди, ності у повному обсязі. Саме для цього необ- 
хідним є обов'язкове призначення СПЕ щодо неповнолітніх жертв насильницьких посягань, бо вікові особливості дитини можуть бути залишені по за увагою суду.

СПЕ займає важливе місце у досудовому розслідуванні та судовому провадженні в якості доказу. Але, незважаючи на визначену законом норму, використання психологічних знань при розслідуванні злочинів, пов'язаних 3 насильством щодо неповнолітніх, працівники органів досудового слідства та судді часто не розмежовують судово-психологічну та комплексну психолого-психіатричну експертизу. Вони вважають, що психологопсихіатрична експертиза відноситься до медицини, а отже має перевагу по відношенню до психологічної експертизи і більш достовірні результати.

\section{Натомість психолого-психіатрична} експертиза відноситься до комплексних психологічних експертиз, у яких пріоритетом $\epsilon$ саме психологічний компонент. Хоча, при дослідженні неповнолітніх жертв насильства можна звертатися й до інших комплексних судово-психологічних експертиз, зокрема: психолого-педагогічної, медикопсихологічної, медико-психологопсихіатричної комплексної експертизи. Психолого-психіатрична експертиза призначається у разі, якщо потерпіла дитина мала або набула у наслідок насильства психічний розлад. Однак, коли жертва направляється на психолого-психіатричну експертизу органами досу- дового слідства та судом, без аналізу стану здоров'я дитини, іiї визначають як психічно хвору, що порушує права, честь та гідність особи.

Саме тому, така некомпетентність суб'єктів призначення експертиз обумовлює нехтування сутністю судово-психологічної експертизи, що потребує більш чіткого розмежування даного виду експертного дослідження від суміжних. Особливо, якщо це стосується такого специфічного об'єкта експертизи, як психологічні особливості неповнолітньої жертви насильства.

Мета статті судово-психологічна експертиза неповнолітніх жертв насильства в кримінальному процесі, розробка алгоритму проведення психодіагностичного дослідження.

\section{Аналіз останніх досліджень і публі-} кацій. Останнім часом проблематикою організаційних засад реалізації судовопсихологічної експертизи займались як юристи, так і психологи зокрема, Андреева Л. А., Васильєв В. Л., Гончаренко В. Г., Коновалова В. О., Костицький М. В., Котов Д. П., Коченов М. М., Кудрявцев Й. А., Нор В.Т., Реан А. А., Сафуанов Ф. С., Сітковська О. Д., Шипшин С. С., Шиханцев Г. Г. Разом із тим, залишається по за увагою питання проведення даної експертизи щодо неповнолітніх жертв насильства, що й визначає актуальність обраної теми.

Виділення невирішених раніше час- 
тин загальної проблеми. Неповнолітні жертви насильства - це окремий вид СПЕ через ряд особистісних особливостей особистості неповнолітніх жертв, зокрема, стану безпорадності або беззахисності, які можуть бути обумовлені внутрішніми причинами, такими як малолітній вік, розумова незрілість, фізичні вади, психічний розлад, стан емоційного збудження, а також стан сп'яніння. Крім того, безпорадність може бути обумовлена й зовнішніми чинниками (раптовість посягання, перевага кривдника в силі, знаходження в залежності від кривдника, ізольованість місця події тощо). Тому, постає завдання до методів визначення цих факторів, які в результаті дають змогу визначати особливості обставин та рівень психотравматизації дитини.

Розпочинаючи аналіз проблематики особливості проведення СПЕ щодо неповнолітніх жертв насильства необхідним є визначення самого поняття «насильство», яке включає в себе: сексуальне, фізичне та психологічне насильства 3 метою розуміння впливу такого посягання на психіку дитини.

Сексуальне насильство - це протиправні дії сексуального характеру, які направлені на посягання щодо статевої недоторканості дитини, залучення дитини за іії згодою або без такої до сексуальних дій 3 дорослим 3 метою отримання останнім сексуального задоволення. Сексуальне насильство може супроводжуватись як фізичним, так і психологічним насильством [3, с. 52].
Сексуальне насильство має наступні форми: вагінальний, неприродним шляхом (оральний, анальний, маніпуляції пальцями або іншими предметами статевих органів дитини), ігри сексуального характеру, імітація статевого акту, вимога спати в одному ліжку 3 особою іншої статі, залучення дитини до комерційного сексу, створення умов, за яких дитина постійно спостерігає за статевими стосунками інших людей, підглядання за дитиною, розбещення шляхом спілкування 3 дитиною в соціальних мережах.

За віковою ознакою сексуальне насильство також може мати місце як серед однолітків, так і з особами старшого віку. У ракурсі близькості соціального статусу насильника, посягання може відбуватися 3 боку незнайомих осіб, або ж з боку найближчого, і зокрема родинного оточення. При цьому, найбільшої травматизації дитина зазнає, коли насильство скоєне членом родини. Пов'язано це з тим, що дитина сприймає членів сім’ї в першу чергу як своїх захисників, які не можуть ії скривдити, тому дуже часто дитина не усвідомлює протиправних характер діянь по відношенню до неї.

Психологічне насильство пов'язане 3 дією особи на психіку дитини шляхом словесних образ або погроз, переслідувань, залякувань, недовіри, якими навмисно викликається невпевненість, відчуття беззахисності, страх, що призводить до завдання шкоди психічному здоров’ю дитини. Психологічне насильство 
може проявлятись у таких формах: нехтування дитиною - нездатність батьків або опікунів дитини створити їй належні умови (матеріальні, побутові, психологічні, соціальні, моральні та ін.) існування та розвитку. У свою чергу психологічне жорстке поводження - це постійне приниження та знущання над дитиною [3, с. 54].

Фізичне насильство визначається як навмисне нанесення дитині фізичних ушкоджень, що може привести до смерті або каліцтва дитини, порушення фізичного чи психічного здоров'я, заподіяння шкоди їі честі і гідності [3, с. 51].

До фізичного насильства відноситься: порушення цілісності органів та тканин організму; побої, удари, грубі штурхання та штовхання; позбавлення їжі, пиття та сну; вплив на дитину із застосуванням фізичних властивостей предметів і явищ середовища.

Відтак, для з'ясування фізичної шкоди призначається судово-медична експертиза, але, зважаючи на психологічну травматизацію жертви, не можна ігнорувати встановлення іiі психологічного статусу, що потребує обов'язкового призначення СПЕ, адже будь-яке суттєве посягання завжди, більшою або меншою мірою відбивається на психічному благополуччі особи.

Таким чином, судово-психологічна експертиза $є$ процесуальною дією, яка полягає у дослідженні психічної діяльності людини що не виходить за межі норми, та проводяться за дорученням органу досудового слідства та суду, або ж ініціюється адвокатом. СПЕ уповноважена проводити компетентна особа, що має спеціальні знання в галузі психології і відповідну експертну кваліфікацію.

Результати проведеної СПЕ процесуально закріплюються у формі висновку що містять у собі відомості про встановлені факти, відповідно до поставлених запитань, або ж додаткові обставини, які не були сформульовані замовником, але мають суттєве значення для кваліфікації протиправного діяння. Такий експертний висновок $є$ самостійним засобом доказування у провадженні [5, с. 201].

У контексті теми нашого дослідження, об'єктом даного виду експертизи є психічний стан неповнолітньої жертви насильницького посягання, особливості іiї пізнавальних процесів, соціального інтелекту, емоційно-вольової сфери, індивідуально-психологічні та особистісні особливості, а предметом - здатність розуміти характер і значення злочинного посягання та надавати їм усвідомлений опір [7].

В. Т. Нор визначає загальним предметом судово-психологічної експертизи психічну діяльність особи у юридично значимих ситуаціях в рамках конкретної справи [5, с. 204].

Підкреслюючи нерозривний зв'язок таких категорій судової експертизи, як її предмет та об'єкт, важливо виділити чотири підходи до розгляду об'єкта судово-психологічної експертизи:

- як психіки досліджуваного в цілому 
та її психічних проявів

(В. О. Коновалова, М. В. Костицький, Г. Г. Шиханцев);

- як психічної діяльності, взятої в сукупності та єдності (Ф. С. Сафуанов, В. Л. Васильєв);

- як джерела інформації: матеріального та ідеального (М. М. Коченов, Й. А. Кудрявцев, О. Д. Сітковська);

- як людини, суб'єкта експериментального дослідження, та відомості про психічні явища учасника процесу, що містяться у матеріалах справи (Д. П. Котов, В. Г. Гончаренко) [5, c. 204].

О. М. Холопова вважає, що правове значення визначається не тільки якістю психологічного дослідження, але й процесуальною формою призначення і проведення судовопсихологічної експертизи, наявністю органічного зв'язку між встановленими обставинами психологічного характеру та елементами предмету доказування

Завданнями судово-психологічної експертизи неповнолітніх жертв насильства $є$ не лише визначення психологічної травматизації жертви посягання, але й встановлення за допомогою спеціальних психологічних знань факту перебування потерпілої в момент посягання в стані безпорадності, тобто нездатності правильно розуміти характер і значення протиправних дій та можливості чинити опір.

Окрім того, експертному встановленню підлягає й психологічні особливості потерпілих, як об’єктивна можливість дати свідчення, що виявляють реальні обставини злочину та які характеризують особистість злочинця. При цьому на об'єктивність свідчень впливають дві групи чинників:

$\Rightarrow$ Об'єктивні (зовнішня ситуація, що пов'язана 3 особливостями сприйняття потерпілим злочинних дій).

$\Rightarrow$ Суб'єктивні (зумовлені особливостями особистості потерпілого та його становищем) [6].

Виходячи із питань, які виносяться на СПЕ дослідженню підлягають наступні психологічні особливості особистості:

1. здатність неповнолітньої жертви насилля, 3 урахуванням ii індивідуальнопсихологічних та вікових особливостей, стану розумового розвитку правильно сприймати обставини, що мають значення для провадження і давати про них правильні показання;

2. здатність жертви правильно сприймати характер і значення дій, що з ними вчиняли та чинити опір;

3. встановлення особливостей виховання, проживання неповнолітнього, а також психологічних компонентів обставин, що сприяють вчиненню злочину;

4. характер психоемоційної травми (як наслідок насильства).

5. психологічний профіль особистості потерпілого.

Зауважимо, що важливим для експертизи є вік жертви сексуального насильства. Сучасне законодавство виділяє категорію 
«неповнолітніх» жертв. Для психологів ця категорія поділяється на більшу кількість вікових періодів, що мають визначальне значення для проведення психодіагностичного дослідження. Отже, психолог-експерт має знати норми розвитку кожного вікового періоду i враховувати це при встановленні наслідків психотравматизації дитини.

Ознаками психотравматизації дитини внаслідок посягання можуть бути:

А) У дітей дошкільного віку: нічні кошмари, страхи, регресивна поведінка (поява дій або вчинків, характерних для більш молодшого віку), невластиві характеру сексуальні ігри з самим собою, однолітками або іграшками, невластиві віку знання про сексуальну поведінку, безпричинні нервово-психічні розлади.

Б) У дітей молодшого шкільного віку: «безпідставне» зниження успішності навчання, виникнення замкнутості та прагнення до усамітнення, різка зміна рольової поведінки (бере на себе функції батька), раптове погіршення взаємин $з$ однолітками, невластива віку, сексуально забарвлена поведінка, прагнення повністю закрити тіло одягом, навіть якщо в цьому немає необхідності.

В) У дітей старшого шкільного віку, підлітків: депресія, втечі $з$ дому або інституційних установ, низька самооцінка, спроби самогубства, сексуалізована поведінка, вживання наркотиків або алкоголю, проституція або безладні статеві зв'язки, психосоматичні розлади [2].

Наступним, на що повинен звернути увагу експерт, - це особистість самого злочинця, адже, як нами вже зазначалося, ступінь психотравматизації неповнолітньої жертви насильства залежить й від ступеня родинних зв'язків із агресором, а також його особистісна значущість для дитини. У даному випадку вважається, що найбільшої травматизації дитина зазнає коли кривдником $є$ рідна людина. Звісно, що характер сили травматизації від близького родича має свої особливості, наприклад, коли батька немає, а є вітчим і дитина сприймає його як людину сторонню.

Слід зазначити, що психічні відбитки травматичної події залежать й від проміжку часу (відтермінованість), з моменту посягання й до моменту проведення експертизи. Чим більше часу проходить, тим важче визначити сліди психотравматизації жертви, адже за умов здорової психіки дитини та навіть відсутності психотерапії, будь-яка дитина намагатиметься забути про злочин, який було скоєно відносно неї. Інколи такі наслідки можна спостерігати у вигляді девіантної, делінквентної та адиктивної поведінки. Тому перед експертом постане завдання відмежувати, ознаки, які вплинули на дитину та призвели до змін поведінки. Хоча, слід розмежовувати за наслідками й гострий стресовий розлад, який настає одразу у момент посягання та поступово згасає, і ПТСР, як відтерміновану у часі стресову реакцію. 
Одним із головних факторів виступає й система взаємовідносин у родині неповнолітньої жертви насильства. Можливо в сім'ї жертви було присутне фізичне, психологічне або сексуальне насильство, що може породжувати більш сильну психологічну травму для дитини. Звертається увага на матеріальне становище родини, особливості виховання та навчання дитини та склад сім’ї. Всі ці дані необхідно обов'язково враховувати експерту при визначенні особливостей соціального оточення $\mathrm{i}$ характеру взаємовідносин, завдяки чому стає можливим встановлення рівня психотравматизації жертви сексуального посягання.

Будуючи психодіагностичне дослідження експерт може використовувати наступні методи: спостереження, бесіду, експеримент природний (в разі відтворення обставин злочину) та лабораторний, біографічний метод, метод аналізу матеріалів кримінального провадження.

Зазвичай, судово-психологічна експертиза вирішує питання стосовно особливостей психічних процесів, емоційних станів, психологічні особливості особистості підекспертного. Тому, факторами, які необхідно враховувати при проведенні СПЕ наповнолітньої жертви насильства мають бути:

- Вік дитини.

- Індивідуально-психологічні особливості дитини.

- Особистісні особливості кривдника.

- Особистісна значущість для жертви осо- би кривдника (людиною близького оточення чи незнайомою).

- $\quad$ Характер насильства (у т.ч. поєднання 3 іншими видами насильства).

- Систематичність посягань.

- Відповідність психологічного віку біологічному.

Особливості взаємовідносин в сім’ї.

- $\quad$ Відтермінованість від моменту злочину до експертизи.

Для розв'язання поставлених завдань пропонуємо структуру проведення психологічного дослідження для всіх категорій, а саме:

1. Вивчення матеріалів кримінального провадження.

2. Встановлення психологічного контакту з дитиною.

3. Психодіагностика.

4. Завершення експертного дослідження.

5. Підготовка та видача експертного висновку.

1. Вивчення матеріалів кримінального провадження полягає у психологічному аналізі матеріалів, особливостей і мотивів скоєного правопорушення. Психологічний сенс співвідношення суб'єктивних даних (протоколи допитів учасників процесу та пояснення спеціалістів) і об'єктивних показників отриманих під час розслідування [1]. Головними критеріями які необхідно визначити експертупсихологу для підготовки психодіагностичного дослідження виступають: вік дитини, осо- 
бистісні особливості кривдника, особистісна значущість для неповнолітньої жертви особа кривдника, характер насильства, системність посягань, особливості взаємовідносин в сім’ї жертви насильства та відтермінованість злочину.

2. Для встановлення психологічного контакту з дитиною необхідною умовою виступає провідна діяльність дитини: в дошкільному віці - це гра, молодший та підлітковий вік - навчання. Отже, для дошкільного віку доцільним буде використовувати методи,які в собі мають елементи гри - малювання фарбами, сюжетна гра іграшками, робота з глиною тощо. Для підліткового віку використовуються проективні методики, такі як «Дім-ДеревоЛюдина», «Неіснуюча тварина», «Малюнок сім’ї». Для молодшого шкільного віку пропонуємо поєднувати ігрові методи з проективними методиками.

3. Психодіагностичне дослідження повинно складатись із:

- Спостереження - для будь-якої вікової категорії.

- Бесіда - визначає обставини злочину (розробляється на основі критеріїв, які необхідно визначити експертупсихологу для підготовки психодіагностичного дослідження).

- $\quad$ Інтерв’ю - розробляється експертом на основі методики опитувальника травматичного стресу та особливостями обставин злочину.
- П Психодіагностичний інструментарій.

Розглянемо особливості психодіагностики відповідно до вікових особливостей:

Дошкільний вік:

1. Ранній вік (від 1 року до 3 років) психодіагностика зводиться до збору інформації шляхом спостереження, а головним методом $є$ природний експеримент в процесі предметної гри.

2. Молодший і середній дошкільний вік (3-5 років) - методики повинні бути направлені не лише на індивідуальну предметну діяльність, а й на колективну гру сюжетнорольового характеру.

3. Старший дошкільний вік (від 5 до 7 років) - до основного виду діяльності додаються ігри з правилами і окрім того, з'являються елементарні рефлексивні здібності [5, с. $60]$.

Виходячи із питань, які виносяться на судово-психологічну експертизу неповнолітніх жертв насильства віком від 3 до 7 років психодіагностичний інструментарій повинен бути направлений на:

1. Стан розумового розвитку. Можна використати будь-які надійні та валідні методики психодіагностики пізнавальних процесів, які відповідають віку дитини. Наприклад, стандартизований комплекс психодіагностичних методик запропонований Р. С. Немовим [4].

2. Характер психоемоційної травми. Найбільш доцільним вважаємо використання кольорового тесту Люшера - для виявлення 
психоемоційного стану дитини; «Обери необхідне обличчя» Р. Теммла, М. Доркі, В. Амена (методика розрахована для дітей віком від 3,5 до 7 років, але якщо дитина достатньо розвинута, то методику можливо використовувати i для дітей 3 років); методика «Обери обличчя для кожного члена родини» - ідентифікація близьких за допомогою облич з різними видами.

3. Особливості виховання та сімейних взаємовідносин - окрім вивчення матеріалів кримінального провадження (характеристики 3 навчальних закладів, протоколи допитів родичів, пояснення спеціалістів) та спостереження за поведінкою дитини під час експертизи можна аналізувати отримані результати за методикою «Обери необхідне обличчя»; ДАТ; тест «Малюнок сім'ї», методика Рене Жиля (за умови відповідності норми розвитку дитини і дитина вміє малювати та розмовляти).

Психодіагностичне дослідження молодиих иколярів (віком від 6 до 11 років) характеризується особливостями рівня психічного розвитку, зокрема, інтелектуальним, моральним та міжособистісним [4, с. 157].

Психодіагностичний інструментарій, відповідно до питань, які виносяться на експертизу, повинен складатись 3 наступних методик:

1. Стан розумового розвитку - можливе використання будь-яких надійних та валідних методик психодіагностики пізнавальних процесів, які повинні відповідати віку ди- тини. Наприклад, стандартизований комплекс психодіагностичних методик запропонований Р.С. Немовим [4].

2. Особливості виховання та сімейних взаємовідносин - вивчення матеріалів кримінального провадження, спостереження за поведінкою дитини, тест «Малюнок сім'ї», методика Рене Жиля, методика репертуарних решіток Дж. Келлі.

3. Здатність правильно сприймати характер і значення дій, що вчиняли 3 дитиною та чинити опір - в даному випадку виникає проблема розмежування здатності дитини правильно сприймати характер злочинних посягань від близького родича (особливо це виражається у злочинах сексуального насилля) так як дитина знає і розуміє те, що близькі родичі являються iï захисниками і не можуть іiі скривдити. Тому, розмежування здатності дитини правильно сприймати характер злочинних посягань необхідно визначати за результатами особливостей взаємовідносин із кривдником (якщо це близький родич) та бесідою, яка окрім основних критеріїв обставин злочину має містити в собі деталізацію дитиною обставин злочину.

4. Характер психоемоційної травми найбільш доцільним вважаємо використання кольорового тесту Люшера - для виявлення психоемоційного стану дитини; методики «Дім-Дерево-Людина» або «Неіснуюча тварина». Але, необхідно враховувати, якщо злочин був скоєний близьким родичем і дитина не 
розуміла характеру злочинних посягань, то ознаки психоемоційної травми можуть бути відсутні.

Психодіагностичне дослідження підліткового та юнаџького віку (від 12 до 18 років). Даний віковий період містить в собі ранній юнацький вік (від 12 до 16 років) та середній юнацький вік (від 16 до 18 років). Головною особливістю для експертного дослідження виступає особливості нормативної свідомості та нормативної регуляції поведінки. Якщо в молодшому шкільному віці діти орієнтуються на соціальні норми, то в підлітковому віці орієнтація спрямовується на однолітків (норми спрямовані не тільки на персоніфікацію, а й в соціалізованій формі) [4, с. 272].

Психодіагностичний інструментарій, відповідно до питань, які виносяться на експертизу, повинен складатись 3 наступних методик:

1. Стан розумового розвитку - можливе використання будь-яких надійних та валідних методик психодіагностики пізнавальних процесів, які повинні відповідати віку дитини. Наприклад, стандартизований комплекс психодіагностичних методик запропонований Р.С. Немовим [4].

2. Особливості виховання та сімейних взаємовідносин - вивчення матеріалів кримінального провадження, спостереження за поведінкою дитини, тест «Малюнок сім'ї», ТАТ; методика Рене Жиля, Методика репертуарних решіток Дж. Келлі (на нашу думку, ця методи- ка виступає пріоритетною).

3. Здатність правильно сприймати характер і значення дій, що вчиняли 3 дитиною та чинити опір - якщо злочинні посягання тривали 3 молодшого дошкільного віку, то діагностика проводиться так само як і в молодшому дошкільному віці, з метою визначення сприймання дитиною злочинних посягань. Якщо злочин був скоєний вперше в підлітковому віці, то на основі отриманих результатів особливостей сімейних (якщо кривдник із близького оточення) взаємовідносин та деталізованої бесіди.

4. Характер психоемоційної травми найбільш доцільним вважаємо використання кольорового тесту Люшера - для виявлення психоемоційного стану дитини; методики «Дім-Дерево-Людина» або «Неіснуюча тварина». А також використання стандартизованих методик, які визначають рівень психоемоційної травми.

4. Завершення експертного дослідження. По закінченню дослідження експерт повинен відзначити гарну роботу дитини і виразити їй найкращі побажання. Якщо у дитини виникли якісь запитання, то дати на них відповідь.

5. Підготовка та видача експертного висновку. Психологічний висновок розробляється на основі нормативно-правових актів, які регламентують діяльність судових експертів України. Він включає в себе аналіз результатів психологічного дослідження, в якому 
визначаються найбільш суттєві показники психічного розвитку дитини; акцентується увага на неадекватні поведінкові реакції; надаються відповіді на запитання, які були поставлені.

Висновки: судово-психологічна експертиза неповнолітніх жертв насильства в кримінальному процесі займає важливе місце, особливо це стосується тих випадків, коли відсутні прямі докази. Але через некомпетентність досудових органів неповнолітні жертви насильства не направляються на СПЕ і втрачається можливість встановлення правосуддя.

Проведення СПЕ вимагає від психолога-експерта не лише компетентності проведення такого виду дослідження, а й відповідальності за проведену роботу і висновки, адже висновок експерта являється самостійним доказом.

Авторський підхід до алгоритму проведення СПЕ неповнолітніх жертв насильства $€$ інструментарієм за допомогою якого визначаються основні критерії від вивчення матеріалів кримінального провадження до моменту завершення психодіагностичного дослідження та підготовки висновків.

Наступним етапом нашого наукового дослідження планується розробка особливостей психотравматизації дитини від насильницьких посягань відповідно до вікових періодів.

\section{Перелік використаних джерел:}

1. Балабанова Л. M. Судебная патопсихология (вопросы определения нормы и отклонений) / Л. М. Балабанова. - Д.: Сталкер, 1998. - 432 с.

2. Жестокое обращение с детьми и подростками: причины, признаки, способы профилактики и оказания помощи / Под ред. И.В. Исаевой. - Нижневартовск [Електронний ресурс]. - 2004. - Режим доступу до реcypcy: nvobrazovanie.ru/data/File/Otdel/OPPS/RMO.doc

3. Методичні рекомендації щодо опитування дітей, що стали свідками та/або жертвами насильства, а також вчинили насильство/ за заг. ред.

Т. Цюман. - К.: СТ-ДРУК, 2015 - 114 с.

4. Немов Р. С. Психология : учеб. для студ. высш. пед. учеб. заведений : в 3 кн. / Р.С. Немов. - 4-е изд. - М.: Гуманитар. изд. Центр ВЛАДОС, 2004. - Кн. 3. Психодиагностика. Введение в научное психологическое исследование с элементами математической статистики. $631 \mathrm{c}$.

5. Основи загальної та юридичної психологіі: Курс лекцій. Навч. посібн. / Н.Р. Бобечко, В.П. Бойко, І.В. Жолнович, І.І. Когутич; ред. В.Т. Нора. - К.: Алетра ; ЦУ Л, 2016. - 224 c.

6. Сас М. В. Психологічні аспекти віктимології в діяльності слідчого // Митна справа. - 2004. - №4 - С. 87-94

7. Шипшин C. С. Психодиагностика жертв сексуального насилия [Електронний ресурс]. - 2000. - Режим доступу до ресурсу: www.iuvenilejustice.ru.

\section{References (Transliteration):}

1. Balabanova L. M. Sudebnaya patopsihologiya (voprosyi opredeleniya normyi i otkloneniy) / L. M. Balabanova. D.: Stalker, 1998. -432 s.

2. Zhestokoe obraschenie s detmi i podrostkami: prichinyi, priznaki, sposobyi profilaktiki i okazaniya pomoschi / Pod red. I.V. Isaevoy. - Nizhnevartovsk [Elektronniy resurs]. - 
2004. - Rezhim dostupu do resursu: nvobrazovanie.ru / data/File/Otdel/OPPS/RMO.doc

3. Metodichni rekomendatsiyi schodo opituvannya ditey, scho stali svidkami ta/abo zhertvami nasilstva, a takozh vchinili nasilstvo/ za zag. red. T. Tsyuman. - K.: STDRUK, 2015 - $114 \mathrm{~s}$.

4. Nemov R. S. Psihologiya : ucheb. dlya stud. vyissh. ped. ucheb. zavedeniy : v 3 kn. / R.S. Nemov. - 4-e izd. - M.: Gumanitar. izd. Tsentr VLADOS, 2004. - Kn. 3. Psihodiagnostika. Vvedenie $\mathrm{v}$ nauchnoe psihologicheskoe issledovanie s elementami matematicheskoy statistiki. $631 \mathrm{~s}$.

5. Osnovi zagalnoyi ta yuridichnoyi psihologiyi: Kurs lektsiy. Navch. posibn. / N. R. Bobechko, V. P. Boyko, I. V. Zholnovich, I. I. Kogutich; red. V. T. Nora. - K.: Aletra ; TsU L, 2016. - 224 s.

6. Sas M. V. PsihologichnI aspekti viktimologiyi v diyalnosti slidchogo // Mitna sprava. - 2004. - \#4 - S. 8794.

7. Shipshin S. S. Psihodiagnostika zhertv seksualnogo nasiliya [Elektronniy resurs]. - 2000. - Rezhim dostupu do resursu: www.iuvenilejustice.ru.

\section{Kozlova Anna Georgievna}

PhD student of the department of Psychodiagnosis and clinical psychology at Kyiv National Taras Shevenko University, Kyiv (Ukraine)

THE ROLE OF FORENSIC PSYCHOLOGICAL EXAMINATION IN CRIMINAL PROCESS AND THE ALGORITHM OF PSYCHODIAGNOSTIC RESEARCH JUVENILE VICTIMS VIOLENCE

\section{ABSTRACT}

Forensic psychological examination is a special research and assessment of phenomena the legal reality by specialist in psychology. This special psychological research conducted in unpsychological area - the practice of law enforce- ment or judicial authorities.

Criminal legal significance forensic psychological examination is individualizing punishment and the correct qualification of the crime according to the damage which the victim came into assault. Trauma of juvenile victims of violent assault can be not only obvious (physical), but not obvious (psychological).

Forensic psychological examination has an important place in the pre-trial investigation and court proceedings as evidence, but despite certain statutory rules, the use of psychological knowledge in the investigation of crimes related to violence against juvenile, officials of the preliminary investigation and judges often do not differentiate forensic psychological and complex psychological-psychiatric examination.

They thinking that psychologicalpsychiatric examination relate to medicine, and therefore have an advantage against the psychological examination and more reliable results.

When the victim is directed to the psychological-psychiatric examination by the preliminary investigation and the court, not previously analyzed the health status of the child, it is defined as a mentally ill person that violates the rights, honor and dignity.

Hence, forensic psychological examination is the processual action, which is in researching of human mental activity that does not extend beyond the norm, and conducted on behalf of the pre-trial investigation or the court, or initiated lawyer. 
Common subject of forensic psychological examination of mental activity a person legally significant situations within particular case. In the context of our research themes the object of this type of examination is the mental state of the juvenile victims of violent attacks, especially its cognitive processes, social intelligence, emotional and volitional, individual psychological and personality traits, and the subject - the ability to understand the nature and importance of criminal assault and provide them conscious resistance

Forensic psychological examination of juvenile victims of violence - a special kind of expertise that requires expert psychologist fundamental knowledge not only the basics of psychodiagnostics, but also developmental psychology; ability to carefully examine materials of the criminal proceedings and by analyzing the right to develop his research according to character of crimes and the age of the child.

Key words: algorithm, psychological diagnostics, psychological violence, sexual violence, forensic psychological examination, juvenile victims of violence, physical violence.

\section{Козлова Анна Георгевна}

Аспирант кафедры психодиагностики и клинической психологии, Киевского национального университета имени Тараса Шевченко, г. Киев (Украина)

\section{МЕСТО СУДЕБНО-}

ПСИХОЛОГИЧЕСКОЙ ЭКСПЕРТИЗЫ В УГОЛОВНОМ ПРОЦЕССЕ. АЛГОРИТМ ПРОВЕДЕНИЯ ПСИХОДИАГНОСТИЧЕСКОГО ИССЛЕДОВАНИЯ НЕСОВЕРШЕННОЛЕТНИХ ЖЕРТВ НАСИЛИЯ

Аннотация. В данной статье раскрыты основные положения по организации и проведению судебно-психологической экспертизы несовершеннолетних жертв насилия. Рассмотрены понятие физического, сексуального и психологического насилия над ребенком. Теоретически проанализировано место судебнопсихологической экспертизы несовершеннолетних жертв насилия и ее значение в уголовном процессе. Определены предмет, объект и задачи судебно-психологической экспертизы. Рассмотрены особенности проявления психотравматизации ребенка как следствие насилия. Разработан алгоритм психодиагностического инструментария в соответствии с возрастными периодами несовершеннолетних жертв насилия.

Ключевые слова: алгоритм, психодиагностика, психологическое насилие, сексуальное насилие, судебно-психологическая экспертиза, несовершеннолетний жертва насилия, физическое насилие.

Дата отримання статті: 01.03.2017

Дата рекомендації до друку: 03.03.2017 